\title{
Uluslararası Habercilik ve Söylem: Türkiye'deki Gazetelerin Suriye İç Savaşını Yansıtma Biçimleri
}

Ömer ONGUN

galatasaray üniversitesi stratejik iletișim yönetimi yüksek lisans öğrencis omerong@gmail.com

\section{Abstract}

International Journalism and Discourse: Manners of Projection of Syrian Civil War in Newspapers of Turkey

Using freedom of communication on behalf of public, the press has been recognized as the fourth estate together with legislation, execution and jurisdiction. Newspapers are the means of this estate which informs, manipulates and shapes the opinions of public. Language and expression, discourse and semantic construction of a news are substantive elements and sources of configuring public opinion. The news of Hürriyet and Birgün in the period of 2-10 October, 2012 on the conflicts occurring in Syria have been analyzed based on Van Dijk's "News Discourse Analysis Method" as part of this work.

keywords: Turkish press, conflict in Syria, critical discourse analysis, news 


\section{Résumé}

Reportage International et Discours: Les formes de la Projection de la Guerre Civile en Syrie par des Journeaux en Turquie

La presse qui est basé sur l'expression de la liberté de communication au nom du public, doit etre considérée comme un quatrèime pouvoir après les pouvoirs legistatif, exécutif et judiciaire. Autrement dit, pour la presse, la liberté de communication est un pouvoir pour pouvoir transmettre les informations en transparence. Le langage, la façon de dire, le style, les raisons de la sélections des nouvelles ou les sujets des textes écrits dans des journaux sont essentiels pour manipuler et influencer les idées des interlocuteurs lainsi que celles du public), il est aussi considerable comment et pourquoi ils sont cités les textes et quel titre qu'on doit choisir. Cette étude qui est faite dans le cadre de "I'Analyse de discours critique" de Van Dijk, a été analysé en prenant en considération les nouvelles des journaux de Birgün et Hürriyet qui étaient publiées entre 2 et 10 Octobre 2012, en Turquie, sur la guerre civile en Syrie.

mots-clés : la presse Turque, les conflits en Syrie, l'analyse critique du discours, les nouvelles

\section{Özet}

Iletişim özgürlüğünü halk adına kullanarak kamusal bir nitelik edinen basın, yasama, yürütme ve yargıdan sonra dördüncü kuvvet olarak benimsenmektedir. Kamuları bilgilendiren, manipüle eden ve kamusal görüșleri șekillendiren bir kuvvetin araçları olan gazetelerde yer alan yazılı metinlerdeki dil kullanımı, üslup, hangi haberin nasıl ve neden seçildiği, başlıklandırıldığı ve aktarıldığı okurun ve dolayısıyla kamunun görüşlerini etkileyerek șekillendirmede oldukça önemlidir. Bu çalışmada 2-10 Ekim 2012 tarihleri arasında Türkiye'de yayınlanan Birgün ve Hürriyet gazetelerinde yer alan Suriye iç savaşına ait haberler Van Dijk'in "Eleştirel Söylem Analizi" temel alınarak incelenmiştir. haber

anahtar kelimeler: Türkiye basını, Suriye savaşı, eleştirel söylem analizi,

\section{Araştırma Metodu: Eleştirel Söylem Analizi}

Mevcut çalışma kapsamında 2-10 Ekim 2012 tarihleri arasında yer alan Suriye iç savașına ait haberler incelenmiștir. Bu çalışmada Türkiye'deki iki farklı gazetenin konuyu ele alış biçimleri arasındaki farkların ortaya konması amaçlanmaktadır. Benimsenen araştırma yöntemi eleştirel söylem analizidir.

Çalışma kapsamında belirlenen aralığın seçiminde, uluslararası basında yer alabilecek boyutta haberlerin bulunmasına dikkat edilmiştir. 2-10 Ekim 2012 tarihi, Suriye iç savaşının ikinci senesinin sonuna yaklaşırken Türkiye'nin, diğer ülkelerin ve uluslararası birliklerin süreçte yoğun olarak rol aldığı hafta olması açısından önemlidir. Suriye Cumhuriyeti Devlet Başkanı Beşar Esad'ın Halep'e gelerek, Türkiye sınırına kadar olan bölgenin muhaliflerden temizlenmesine yönelik operasyon için emir verdiği iddiası, İngiltere'nin önde gelen gazetelerinden Independent gazetesinin Suriye'deki hükümet karşıtı isyancıların ellerinde ağır silahlar bulunduğu ve isyancı gruplar arasındaki çatışmadan kaynaklı bu silahların dağıtılmadığı ve Türkiye'de tutulduğu iddiası, Türkiye'ye düșen top mermisi ve Türkiye'nin karşılık vermesi, Suriye Havayollarına ait yolcu uçağının Türk savaş uçakları tarafından indirilmesi haberlerine yoğunlaşmaya çalışılacaktır.

Çalışma yöntemi olarak eleştirel söylem analizinin seçilmesinin amacı, bir ülkenin iç savaşının diğer ülkelerde ele alınış biçiminin incelenirken eleştirel, sosyal ve politik çözümlemelerin önem arz etmesidir. Van Dijk'ın da vurguladığı gibi eleștirel söylem analizinin bașlı bașına sosyal ve politik bir tutum olması, ülkelerin ve gazetelerin kendi tutum, ideoloji ve değerlerini kendi çıkarları doğrultusunda manipüle etmelerinin gözlemlenmesi açısından uygundur (Çomak ve Inceoğlu 2000: 30). Haberlerde kullanılması tercih edilen ifadelerin biçimsel olarak incelenmesi yeterli olmayacağı için, anlam inşa edilmesi açısından araç olarak kullanılan söylemin incelenmesi gerekmektedir.

Van Dijk'a göre söylem iletişim etkinliği veya iletişimsel eylem bağlamında yakalanabilecek dilbilimsel şekil, anlam ve eylemden oluşan karmaşık bir birimdir. Bir toplantı, mahkeme ya da her türlü diyalog ortamında konuşmacı ve dinleyicinin bireysel ve sosyal özellikleri ve bulunduğu sosyal durum iletişimsel eylemi etkileyecektir. Benzer bir durum haber söylemlerinde de geçerlidir. Haber raporlarının anlaşılması onların bilişsel ve sosyal süreçlerinin, gazetecilerin atfettikleri anlamların ve okurların yorum süreçlerinin analizleriyle olur (Van Dijk 1988: 9)

Medyada kimin konuştuğu, ne söylediği ve söylenenlerin ne anlama geldiği medya söylemlerini analiz etmek adına önemlidir cünkü medyada hangi haberin yer aldığı, hangilerinin göz ardı edildiği ya da görünmediği bir tür söylem oluşturmaktadır. Davis, "Medya söylemindeki anlamın sıklıkla örtük açıklama çerçeveleri ve yorumun temel kuralları içine yerleştirildiğini, bu nedenle de söylemin basitçe okunmasından daha çok keşfedilmesi gerektiğini" belirtir (Cangöz 2003: 39). 
Söylem analizi, metin ve konușmayı söylemin çeșitli seviye ve boyutları için oluşturulan kuramlar aracılığıyla açıklamaktadır. Klasik dilbilimi ve semiyotik, form (signifiants) ve anlam (signifiés) arasında genel bir ayırım yaparken, söylem analizi metin ve konușmanın çok daha karmașık olduğunu kabul eder. Fonetik, grafik, sesbilimsel (fonolojik), morfolojik, sözdizimsel (syntactic), mikro ve semantik, biçemsel, üstyapısal, retorik, pragmatik, sohbetsel, ilişkisel ve diğer yapı ve stratejilerin ayrı ama ilișkili bir sekilde incelemesini gerektirir. Böyle karmaşık bir söylem analizi metinsel analizle sınırlı değildir ve bir yandan metin ve konuşma yapıları arasındaki ilişkiyi açıklarken, diğer yandan bu yapıların bilişsel, toplumsal, kültürel ya da tarihsel bağlamlarını açıklar (Van Dijk 1995: 135)

Rus masal anlatıcısı Vladimir Propp'un morfolojik çalışmalarından günümüze değin gelişerek disiplinleşen söylem analizi, bugün haber raporlarının analizlerinde önem kazanan bir disiplindir.

Haber yazım süreçleri direkt veya pasif süreçler değildir. Sosyal ve ideolojik olarak belirlenmiş, kontrollü ve yapısal stratejiler tarafından belirlenirler. Bir gazetede yer alan bir haber, kültür, etnisite, toplumsal cinsiyet, ulus, siyasi ideoloji ve baskın hedeflerin içinde olduğu sosyal temsillerin etkisi altında yazııı (Van Dijk 1988: 27). Van Dijk ve öğrencilerinin 1988 yılında gerçekleştirdiği "Uluslararası Haberlerin Yapıları: Dünya Basınından Örnekler" çalışması kapsamında 100 ülkeden 250 gazete incelenmiş ve haber söylem yapıları analiz edilmiştir (Van Dijk 1984: 1). Bu çalışma eleştirel söylem analizinin anlaşıması açısından kapsamlı bir örnek sunmaktadır.

\section{Eleştirel Söylem Analizinin Yapıs}

Sınıf, cinsiyet ve etnisite gibi sosyal özellikler ve bunların arasındaki ilişkiler, kendi sosyal, siyasi ve kültürel bağlamlarında metin ve sözün; yapısal birimler, strateji ve seviyeleriyle sistematik olarak ilişkilidir (Van Dijk 1988: 138). Eleștirel söylem analizi, sosyal güç suistimalinin, baskınlığının ve eșitsizliğinin metin ve söz aracılığıyla yeniden üretimine, meşrulaşmasına ve bunlara karşı çıkmaya yol açan noktaları sosyal ve siyasi bir çerçevede inceler.

Dil kullanımı ve söylem, ideolojiler tarafından etkilenen ve bizlerin o ideolojileri nasıl sahiplendiğimizi, öğrendiğimizi veya değiştirdiğimizi de belirleyen önemli sosyal pratiklerdir (Van Dijk 2000: 9). Söylem analizinin ana hedefi, söylem olarak da adlandırdığımız dil kullanım birimlerinin açık ve sistemli bir şekilde açıklamalarının üretilmesidir. Bu açıklamaların iki boyutu bulunmaktadır: metinsel ve bağlamsal boyut (Van Dijk 1988: 24). Metin yapısı çözümlemeleri içerisinde metin semantiği, haber şeması ve üslup ve retorik analizleri bulunmaktadır.

\section{Metin Semantiği}

Semantik, kelimelerin, cümlelerin ve söylemlerin anlamlarıyla ilgilenmektedir (Van Dijk 1988: 25). Metin yapısı çözümlemelerinin așamalarından biri olan metin semantiği içerisinde tümceler ve cümleler arasındaki bağlar, dolaylı anlatımlar ve anlam ilişkilendirmeleri yer almaktadır. Van Dijk haberin cümle yapıları, seçilen kelimeler ve bu kelimelerin cümlelerdeki dizilimi üzerinde durmaktadır. Basit cümleler ve karmaşık cümlelerin kullanımı, cümlelerin uzun ya da kısa yapıları, sözcük ve sözcük öbeklerinin seçimi metin semantiğinin çözümlemede önemlidir. Metin semantiğinde metin önermelerinin zaman, durum, sebep ve sonuç gibi ilişkilerle birbirine bağlı olaylara atıfta bulunmasına dikkat edilir. Kelimeler, cümleler ve diğer metinsel ifadeler arka plan bilgisine dayanılarak çıkarımda bulunulabilecek içerikleri ve iddiaları ima yoluyla ortaya koyabilir. Bu anlamda ima, en güçlü semantik kavramlardan biri sayılır. Metinde varsayımlar, gereklilikler ve çağrışımlar şeklinde ima türleri kullanılabilir (Van Dijk 1988: 25).

\section{Haber Şeması}

Metin yapısı çözümlemelerinin diğer bir aşaması haber şemasıdır. Tüm metinler, kelimeler, cümleler, paragraflar ve bölümlerden oluşmaktadır. Örneğin hikâyeler giriş, gelişme ve sonuç bölümleri içerir. Öyküler, öykünün özetin belirten cümle dizilimleri ile başlar ve bu cümle dizilimlerini, öyküdeki olayların kurgusunu anlatan diğer cümleler izler. Bu kurgu bölümünde yer, zaman, ilişkilerin durumu ve karakterler anlatıır. Özetle, metindeki bölümlerin her birinin farklı fonksiyonları vardır ve bu sebeple metindeki her bir bölüm için farklı spesifik bilgilere ihtiyaç duyulur (Van Dijk 1988: 49)

Haberlerde de, öyküler veya diğer metinler de olduğu gibi farklı bir şema mevcuttur. Haber semasının içerisinde bașlık, haber manșeti, ana olay ve bağlamı, olayla ilgili arka plan bilgileri, sonuç, sözel tepkiler ve yorumlar yer almaktadır (Van Dijk 1988: 53). Aşağıda haber şemasının varsayımsal yapısı gösterilmektedir. 
Şekil 1. Haber Semasının Varsayımsal Yapısı (Van Dijk 1988: 55)

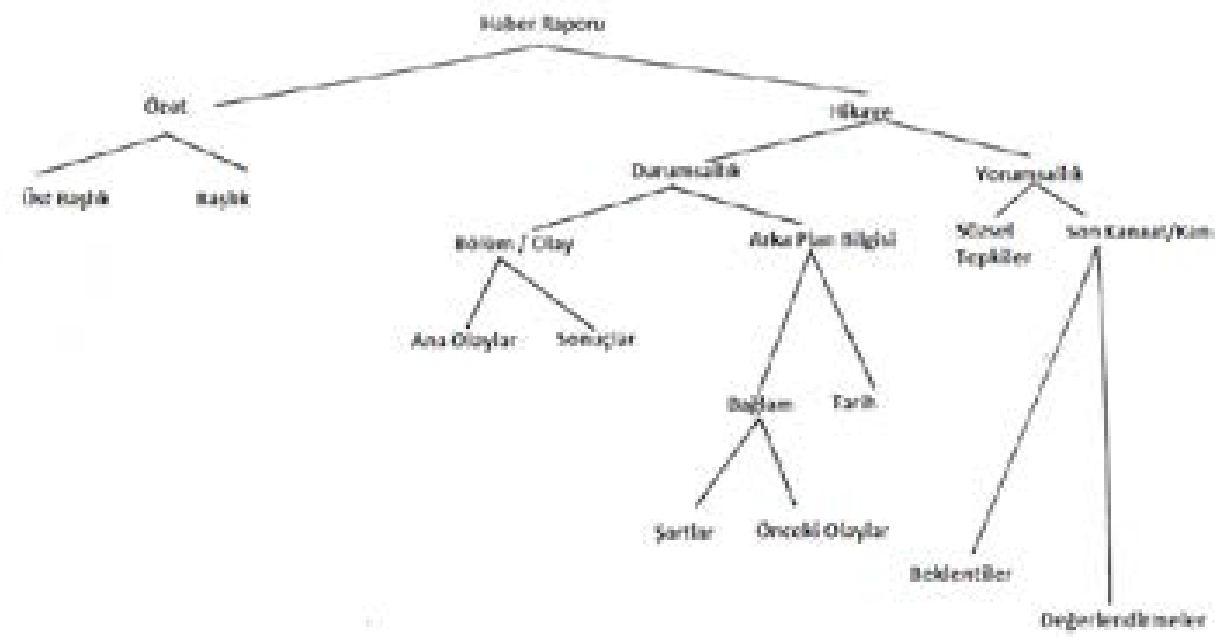

\section{Üslup ve Retorik}

Üslup, genellikle edebiyattaki kișisel özgünlük ve estetik dil kullanımıyla ilișkili ele alınmıștır. Üslup, konuşma ve yazı dilinde çeşitlilik göstermektedir. Ayrıca bu çeşitliliği yaş, cinsiyet, statü, sınıf ve etnisite belirlemektedir. Bir mahkemede veya kamuya yapılan nutukta, konuşmacı, aile veya arkadaşlarla yapılan günlük konuşmalarına göre daha formel bir üslup kullanmaktadır. Yazı dilinde de benzer şekilde konuşma diline göre daha formel bir üslup tercih edilmektedir (Van Dijk 1988: 53). Haber için üslup, muhabirin ya da gazetecinin sosyo-politik ve ideolojik perspektifi hakkında fikir verebilmektedir. Aynı insan için terörist veya özgürlük savaşçısı kelimelerinin kullanılması semantik bir sorun değil, o gazetenin veya gazetecinin kendi duruşunu ve değerlerini belirten bir durumdur.

Retorik, bir şeyi nasıl ifade ettiğimizle ilgilidir. Haberlerin retorik yapılarının kullanımı iletişimde hedeflenen amaçlar ve niyetlenen etkilere bağlıdır. Van Dijk'a göre, haberler ideolojik olarak toplumdaki elit grupların baskın inanç ve düşünce sistemlerinin benimsetilmesini sağlama niyetindedir. Bilgi ve ikna önermelerinin kabul edilmesi karmaşık bir süreçtir. Haberlerde, kanıtlar, geçerli nedenler, görgü tanığı raporları, sayılar, kaynak ve alıntılar sunularak okurun ikna edilmesi hedeflenir (Van Dijk 1988: 82).

\section{Sosyo-Kültürel Bağlam}

Haberin söylemsel analizi yalnızca metinsel yapı ile sınılı değildir. Metin yapıları içerisinde altta yatan anlamlar, fikirler ve ideolojiler ifade edilmekte ya da işaret edilmektedir. Dolayısıyla bu altta yatan anlamların metinle bağlantısının ortaya çıkarılması için bilişsel, sosyal, politik ve kültürel bağlamın da analiz edilmesi gerekmektedir (Van Dijk 2013: 117). Van Dijk'e göre, söylem anlaşılırken, kișiler metni anlamanın ötesinde metinle ilgili, metin, konuşmacı veya durum ile ilgili belirli fikirler üretirler. Bu fikirleri basitçe değerlendirme önermeleri olarak adlandırabiliriz. Bu değerlendirmeler iyi ya da kötü gibi kișisel değerlendirmeler olabileceği gibi 'Basın özgür olmalı' veya 'Nükleer santraller tehlikelidir' gibi daha genel fikirleri de kapsayabilir (Van Dijk 2013: 108). Bilişsel anlam, metinin veya olayın bilgisinin nasıl analiz edildiği, yorumlandığı ve hangi ideolojiye sahip biri tarafından yazıldığı hakkında ipucu vermektedir.

Gazete haberleri analiz edilirken, şu noktaları gösteren istatistik ve tablolar sunulacaktır:

- Haberlerin seçilen tarih aralığına göre dağılımı

- Haberin tarihi, başlığı ve kaynağı

- Haber içerisinde kimlere söz verildiği

\section{Türkiye-Suriye iliş̧kilerine Bakış}

1945 sonrası dünya siyasetinde Batı kampında yer alan Türkiye ile Sovyet kampında yer alan Suriye'nin arası, Hatay konusu da düşünüldüğü zaman hiçbir zaman çok yakın olmamıştır. 1954 yılında hazırlanan Bağdat Paktı, bariz şekilde Mısır, Suriye ve Sovyet blokunu dengeleme niyetindeydi ve bu durum bașta Mısır ile olmak üzere Türkiye'nin bu bloktaki bütün ülkeler ile kriz yaşamasına yol açmıştı (Oran 2001: 621). 1957 yılında Sovyetlerin Suriye ordusu ve siyaset üzerinde artan etkinliği bir Suriye-Türkiye krizine dönüșmüș, savașın eșiğinden S. Arabistan'ın arabuluculuğu ile dönülmüştü (Oran 2001: 631). Ayrıca 1961 yılında Suriye'de darbe ile iktidara gelen askeri cunta BAC'den ayrılma kararını ilk tanıyan ülkenin Türkiye olması da anlamlıdır (Oran 2001: 786). Bunun yanında Demokrat Parti döneminde 1960'lı yıllarda bașlayan yakınlașma, 1967 savașında Türkiye'nin İsrail karşısında Arap ülkelerini destekleyen tavrı ile biraz daha ısınmıștır (Oran 2001: 790). 90'lı yıllarda ise Türkiye'nin uluslararası su kullanım ve baraj yapma kanunlarını hiçe sayan tutumu ve Suriye'nin de tırmanan PKK şiddetine verdiği destek ile ilişkiler en kötü dönemlerinden birine girdi. Abdullah Öcalan'ın yakalanmasıyla sonuçlanan sürecin başında, onu barındıran Suriye ile bir kez daha savaşın eşiğine gelinmişti (Oran 2001: 565).

Uzun zaman boyunca Ortadoğu siyasetinden uzak durma eğiliminde olan yerleşik Türk dış siyaseti AKP ve 2000'ler ile yeni bir döneme girmiştir. Bu çerçevede AKP Ortadoğu'da Türkiye'nin etkisini artırabilmek adına "komşularla sıfır sorun" politikasını ortaya atmış, bu çerçevede babası Hafız Esad ile çok sorun yaşanmış olan Beşar Esad ile yakınlaşma dönemi başlamıştır. Bu yakınlașma dâhilinde ticaret teșvikleri, vize kaldırma ve diğer bașka imtiyazla karşılıklı olarak verilmiş, Türkiye - Suriye ilişkiler tarihinin en sıcak dönemi 
yaşanmıștır. Ama Arap Baharı ile birlikte, iç siyasetinde "söz milletindir" temasına vurgu yapan ve yerleşik laik bürokrasi ile savaşan muhafazakâr eğilimli AKP, Arap ülkelerinde başlayan ve Müslüman Kardeşler'in etkin olduğu devrim hareketlerine Batı ile ortak çıkarları doğrultusunda da destek vermeye başlamış, bu süreç şu an içinde bulunulan Türkiye - Suriye soğuk savaşı sürecine kadar gitmiştir.

\section{Türkiye Yazılı Basın Tarihi}

Türkiye'de basın 19. Yüzyılın ikinci yarısından itibaren gelișmiştir. Avrupa ülkelerinde basılan Arapça ve Türkçe kitapların ülkeye sokulması, Osmanlı bünyesindeki azınlıkların basımevleri kurmaları basım sanatının ülkede gelişmesini sağlamış ve gazeteciliğin temellerini atmıştır (İnuğur 1993: 149). Osmanlı Devleti'nin son yıllarında Tazminat döneminin bir ürünü olarak gazeteler hem bilgi hem de siyasi görüş iletme ve yayma araçları olarak öne çıkıyordu.

Osmanlı Devleti ve Türkiye'de basın hükümetin bir duyuru organı biçiminde başlamıştır. II. Mahmut İzmir'den getirttiği Alexandra Blacque yönetiminde 1830 'da Fransızca olarak "Moniteur Ottoman"ı çıkartmıştır. Türkçe ilk gazete ise 1831 'de özel izinle çıan "Takvim-i Vekayi" olmuștur. Bu gazete 763. sayısından sonra "Resmi Gazete" adını aldı (Besen 1997: 14). Bu tarih çeşitli kaynaklarda basın tarihinin başlangıç noktası olarak kabul edilmektedir (İnuğur 1993: 172). Daha sonra ise 1860'da "Tercüman-ı Ahval" ve onu takiben farklı tarihlerde çeşitli gazeteler yayın hayatına başlamıştır.

Modern Türkiye Cumhuriyeti Devleti'nin kurulduğu ve Harf Devrimi'nin gerçekleștiği 1923 ve sonrasında hükümet, İnkılap, Halk Dostu, Hür Adam, Hür Gazete, Mahfel, Şule, Muhit, Köroğlu, Uyanış, Yarın ve Diken gazetelerini destekledi (İnuğur 1993: 172). Cumhuriyet'e geçiş sürecinde Türk basını devletin kuruluşu ve modernizasyonunda önemli bir araç işlevi görmüştür.

1970ılerde ise gazetecilik alanında önemli teknik gelişmeler görüldü. Ülke çapında yayınlanan birçok gazete renkli ofset basıma geçti. Renkli, resimli magazin ekleri veren gazeteler yaygınlaştı. Özellikle 1980 sonrasında «boyalı basın» da denen bulvar gazetelerinin tirajında büyük artışlar görüldü. Tekelleşme ve tiraj savaşları 90'lı yılların önemli özellikleridir. Türk basınında "Promosyon Devri" olarak da geçen bu dönemde gazeteler çeşitli promosyonlar gerçekleştirmişlerdir (Besen 1997: 15). 90'lı yıllar Türkiye Radyo ve Televizyon Kurumu (TRT)'nin medya alanındaki tekelciliğinin kırıldığı, medya sektörüne yeni oyuncuların dâhil olduğu, TV, radyo ve gazete gibi çoklu medya satın almaların yaşandığı, medya patronlarının medya dışı sektörlerde de yatırımlarının öne çıktığı bir dönem olmuştur.

\section{Günümüzde Türkiye'de Yazılı Basın ve Gazeteler}

2011 yılı verilerine göre Türkiye'de günlük basının yüzde 54'ü üç büyük sermaye grubunun elinde bulunmaktadır. (Güney ve Sözeri 2011: 61). Türk medyasında önemli bir yere sahip Doğan Grubu'na bağlı Doğan Yayın Holding (DYH), gazete, dergi ve kitap yayıncılığı, televizyon, radyo yayıncılığı ve yapımcılığı, internet, dijital dünya, basım, dağıtım ve yeni medya alanlarında çalışmaktadır. DYH'nin şu anda beş gazetesi vardır: Hürriyet, Radikal, Posta, Fanatik, Turkish Daily News. (Doğan Yayın Holding Iilkeleri, 2013,www. doganholding.com.tr) İkinci en büyük grup olan Feza Gazetecilik A.S'ye ait ik gazete vardır: Zaman ve İngilizce yayın yapan Today's Zaman. Şirkete ait olan Zaman Gazetesi 2009 yılı sonuna gelindiğinde gazete satış adedini ortalama 630 binlere çıkararak Türkiye'nin en çok satan gazetesi olmuştur. (Feza Gazetecilik, 2013, http://ik.zaman.com.tr)

Türkiye İstatistik Kurumu (TÜIK) 2011 yazılı medya istatistiklerine göre Türkiye'de 2618 yerel, 91 bölgesel ve 196 ulusal olmak üzere toplam 2905 gazete yayınlanmaktadır. Gazetelerin 55'i kamu, 2683'ü özel sektör ve 167'si ise sivil toplum kuruluşları tarafından yayınlanmaktadır. Gazetelerin \%14,2'si günlük \%31'i haftalık olarak yayın yapmakta ve \%86,3'ü siyasi/haber/güncel içerikli yayın yapmaktadır. (Yazılı Medya İstatistikleri, 2011, www.tuik.gov.tr)

Siyasi açıdan merkez sağda konumlanan Adalet ve Kalkınma Partisi (AKP)'nin 2002 yılının Kasım ayından bu yana iktidarda olduğu Türkiye'de, gazetelerin tirajlarına baktığımızda hükümete yakın veya açıkça destek veren gazetelerin tirajlarındaki artış görülmektedir. 2013 yılında tirajlarına göre ilk ik gazete Feza Grubu'na ait olan ve hükümet yanlısı muhafazakâr bir editoryal bakışa sahip Zaman, neoliberal bir çizgide olan ve İngiltere'nin küçük gazete gazetelerine benzerliğiyle dikkat çeken ve DYH'ye ait olan Posta Gazetesi'dir (Mayıs 2013 Tiraj Raporu, 2013, www.bik.gov.tr) Yine DYH'ye ait olan Hürriyet Gazetesi ise üçüncü sıradadır. Tiraj sıralamasında yukarıdaki gazeteleri takiben Turkuvaz Grubu'na ait olan Sabah Gazetesi de editoryal bakış olarak merkez sağ, neoliberal ve hükümete yakın bir çizgide yayın yapmaktadır. Listede son yıllarda yükseliște olan Sözcü Gazetesi dikkat çekmektedir. Sözcü Gazetesi, ulusalcı ve Kemalist sol çizgisiyle bilinmektedir.

Türkiye'de basın Osmanlı'dan başlayarak hemen her zaman siyasal iktidarların tehdidini üstünde hissetti. Matbaanın kullanılmasında olduğu gibi, basının oluşumunda da batıya göre bir hayli geç kalan Osmanlı İmparatorluğu, ilk gazetenin yayınından itibaren de basını özgürleștiren değil, denetim altına alan mekanizmalara ağırlık verdi. Baskı geleneği, modern cumhuriyet döneminde de varlığını sürdürmüştür (Çakır 2011). Günümüzde Türkiye'deki yazılı basın, sansür, basın özgürlügüne dönük baskılar, gazetecilerin tutuklanması ve yayınlara dönük siyasi müdahale sorunları yaşamaktadır. Freedom House'un (Özgürlük Evi) 2013 
Dünya Basın Özgürlüğü Raporuında Türkiye Ikısmi özgürı ülke sınıflamasına dâhil edilerek 197 ülke arasında 120. sırayı almıştır (Dunham ve Karlekar 2013)

\section{4. Çalışma Kapsamında İncelenen Gazeteler}

Çalışma kapsamında Hürriyet ve Birgün gazeteleri incelenmiştir. Gazeteler seçilirken editoryal bakış açısından farklı görüșleri temsil etmelerine ve Suriye'deki iç savaşla ilgili çeşitli haberler yapmış olmalarına dikkat edilmiştir.

Kurulduğu ilk yıllardan bu yana Türkiye'nin en fazla satan gazetesi olan ancak son yıllarda tirajları düşen Hürriyet Gazetesi "Türkiye Türklerindir!" sloganı ile resmi ideolojilerin destekçisi, rejimin savunucusu ve laikliğin kalesi konumunda olmuştur. Tirajları bakımından bulunduğu siyasi görüş içerisinde en çok satan gazetedir. Mayıs 2013 itibariyle günlük tiraj ortalaması 423.654'dir. (Mayıs 2013 Tiraj Raporu, 2013, www.bik.gov.tr) Doğan Yayın Holding A.Ş'nin sahibi olduğu Hürriyet gazetesi 1 Mayıs 1948'de İstanbul'da kurulmuştur. Basılı gazetenin yanı sıra web-cep-tablet'den de günde milyonlarca kișiye erișmekte ve 65.yılında günde 6.8 milyon ziyaretçiye ulaşmaktadır. DYH, 2012 yıında Yazılı Basın İlkeleri yayınlamıştır. (Yazılı Basın Yayın ilkeleri, 2013, www.imagehk.hurriyet.com.tr) Yayın ilkelerinin 1. Maddesi şöyledir:

"Gazetecilikte temel işlev, gerçekleri bulup bozmadan, abartmadan, sansürlemeden, hiçbir baskı veya çıkar grubunun etkisi altında kalmadan, objektif bir biçimde kamuoyuna iletmektir."

İstanbul'da merkezi bulunan Birgün Gazetesi günlük gazetedir. Sendika, meslek odaları gibi çok ortaklı bir sermaye girișimiyle 2004 yılında kurulan ve "Halkın Gazetesi" olarak lanse edilen Birgün Gazetesi, Özgürlük ve Dayanışma Partisi (ÖDP)'ne yakınlığı ile bilinmektedir ve ülkedeki sol/sosyalist yayınlar arasındadır. Birgün Gazetesi kuruluş amaçlarını şöyle belirtmektedir:

"BiRGÜN her şeyden önce toplumsal muhalefet dalgasının sesi olmayı hedeflemektedir. Toplumsal muhalefet kesimleri; işçiler, gençler, kadınlar, öğrenciler, öğretmenler, profesyoneller, çevreciler onun asıl hedef kitlesidir. Bu toplumsal kesimlerin yalnızca bir okur değil, muhabir-okur olmaları BiRGÜN'ün gücü olacaktır." (Neden Bir Günlük Gazete? Nasıl Bir Günlük Gazete?, 2013, www.birgun.net)

Birgün Gazetesi'nin günlük tirajı 8.101'dir. Gazetenin kurulduğu dönemki tirajı yaklaşık 16.000 iken son yıllarda özellikle sol gruplar ve sendikalar arasında yaşanan ayrışma ve intilafların gazetenin tiraj düşüşünde etkisi olduğuna yönelik görüşler mevcuttur (Altındiş 2009)

Araștırma kapsamında Hürriyet ve Birgün gazetelerinin 2-10 Ekim 2012 tarihleri arasındaki haberleri incelenmiştir. Ele alınan haberler eleştirel söylem analizi üzerinden değerlendirilmiştir.

\section{Gazetelerde Çıkan Haberlerin Değerlendirilmesi}

Suriye iç savaşıyla ilgili Türkçe yayınlanan haberler üzerine yapılan araştırma kapsamında 2-10 Ekim 2012 tarihleri aralığındaki Hürriyet ve Birgün gazeteleri incelenmiştir. Hürriyet Gazetesi'nin internet sitesi hurriyet.com.tr Türkiye'de en fazla ziyaret edilen sekiz internet sitesinden biridir ve her gün ortalama 2 milyon kiși tarafından ziyaret edilmektedir. (Alexa, www.alexa.com) Birgün Gazetesi internet sitesinin ise günde ortalama 25 bin ziyaretçisi vardır. Internet sitelerindeki arşivlerinde yapılan aramalar sonucunda edinilen bulgular Eleştirel Söylem Analizi çerçevesinde değerlendirilmiştir

\subsection{Haber Dağılımları}

Tablo 1: 2-10 Ekim 2012 Tarihlerinde Yayımlanan Ilgili Haberlerin Günlere Göre Dağılımı

\begin{tabular}{|l|l|l|l|l|l|l|l|l|l|}
\hline Gazete Adı & $\mathbf{2 . 1 0}$ & $\mathbf{3 . 1 0}$ & $\mathbf{4 . 1 0}$ & $\mathbf{5 . 1 0}$ & $\mathbf{6 . 1 0}$ & $\mathbf{7 . 1 0}$ & $\mathbf{8 . 1 0}$ & $\mathbf{9 . 1 0}$ & $\mathbf{1 0 . 1 0}$ \\
\hline Birgün & & 2 & 3 & 3 & & & 3 & 2 & 2 \\
\hline Hürriyet & 1 & & 7 & 5 & 4 & 1 & 2 & & \\
\hline
\end{tabular}

Yukarıdaki tabloda da görüldüğü üzere Suriye tarafından açılan ateş sonrasında Şanlıurfa'nın Akçakale ilçesinde 5 Türk vatandaşın hayatını kaybettiği, havan mermisinin Türkiye topraklarına düştüğü ve bunun üzerine Türkiye tarafından karșılık verilerek Türkiye Büyük Millet Meclisi (TBMM) tarafından hükümete yetki veren tezkerenin kabul edildiği 3 ve 4 Ekim tarihlerinde Suriye ile ilgili çıkan haberler her iki gazetede de yoğunlaşmaktadır.

Birgün Gazetesi, havan mermisinin Türkiye topraklarına düşmesini takip eden 4 ve 5 Ekim tarihlerinde haber sayısını artıırken özellikle tezkere kabulüne yönelik tartıșmaların arttığı 8-9 ve 10 Ekim tarihlerinde de konuyla ilgili haberlere yer vermiștir. Hürriyet Gazetesi'nde ise mecliste tezkerenin kabul edildiği tarih olan 4 Ekim'de haber sayısı yediye çıkmış, bunu takiben Suriye savaşı ve tezkere ile ilgili haberler azalarak yer almaya devam etmiştir.

\subsection{Haber Başlıkları}

Sol/sosyalist bir çizgide yayın yapan Birgün Gazetesi'nde inceleme yapılan tarih aralığında 15 adet haber yer almıştır. Bu istatistiğe köşe yazıları dâhil edilmemiştir. Birgün Gazetesi'nde yer alan haberlerin başlıkları ve kaynakları şöyledir: 
Tablo 2: Birgün Gazetesi'nde 2-10 Ekim 2012 Tarihleri Arasında Çıkan Ilgili Haber Başlıkları

\begin{tabular}{|c|c|c|}
\hline Tarih & Haber Başlı̆̆ı & Haberin Kaynağı \\
\hline 03.Eki & Hizbullah komutanları Suriye'de mi öldürüldü? & Yakın Doğu Haber (YDH) \\
\hline 03.Eki & Halep'te bombalı saldırılar: 41 ölü, 91 yaralı: & $\begin{array}{l}\text { Suriye İnsan Hakları Örgütü } \\
\text { (SNHR) }\end{array}$ \\
\hline 04.Eki & $\begin{array}{l}\text { AKP'nin savaş tezkeresi: Zamanı, kapsamı belirsiz, } \\
\text { savaş ilanı anlamına geliyor }\end{array}$ & Internethaber.com \\
\hline 04.Eki & Savaş için tezkere değil şimdi barış zamanı & Birgün \\
\hline 04.Eki & CHP ve BDP 'Hayır' diyecek & Birgün \\
\hline 05.Eki & Savaşa yakın barışa Fransız & Birgün \\
\hline 05.Eki & Kışanak: Gerekirse tankların önüne geçeceğiz & Milliyet \\
\hline 05.Eki & 'Türkiye'nin büyük oyununa dikkat' & Daily Telegraph \\
\hline 08.Eki & Erdoğan: Savaşa hazır değilsen devlet değilsin & Birgün \\
\hline 08.Eki & 'Suriye'de şu anda en kötü senaryo gerçekleşiyor' & Birgün \\
\hline 08.Eki & $\begin{array}{l}\text { Tekin: Suriye'ye savaşa gideceğine Hakkâri'ye } \\
\text { gitsin sayın Başbakan }\end{array}$ & Birgün \\
\hline 09.Eki & Milliyetçi adam ağlamaz, savaşır! & Birgün \\
\hline 09.Eki & 'Bu kafayla olsa olsa Şam babası olursun' & Birgün \\
\hline 10.Eki & $\begin{array}{l}\text { "Esad'a da Obama'ya da 'Canın cehenneme' } \\
\text { derim" }\end{array}$ & Anadolu Ajansı (AA) \\
\hline 10.Eki & $\begin{array}{l}\text { Erdoğan: Suriye'de olayların bugün geldiği nokta, } \\
\text { Türkiye'nin eseri değildir }\end{array}$ & Anka Haber Ajansı (ANKA) \\
\hline
\end{tabular}

Tabloda da görüldüğü gibi Birgün Gazetesi Suriye'deki savaşla ilgili haber kaynakları olarak ana akım ajanslardan ziyade YDH, ANKA ve SNHR gibi farklı kaynaklardan enformasyon sağlamaktadır. YDH, Ortadoğu eksenli haber yapan bir sitedir. Birgün Gazetesi'nin AA dışında ulusal ya da uluslararası ajanslardan haber almadığı görülmektedir. Gazetenin tezkere tartışmalarının yaşandığı dönemdeki haber başlıklarına bakıldığında savaş karşıtı duruşunun öne çıktığı görülmektedir. Savaş için tezkere değil şimdi barış zamanı, CHP ve BDP 'Hayır' diyecek ve AKP'nin savaş tezkeresi: Zamanı, kapsamı belirsiz, savaş ilanı anlamına geliyor başlıkları tezkerenin mecliste kabul edilmesine karşı tutumu göstermektedir. Gazetenin kendisi tarafından yazılan haberler ise Başbakan'ın ve bazı milletvekillerinin basın açıklamaları ve konuşmalarının aktarılmasıdır. Gazetenin Başbakan Erdoğan'ın konuşmalarını aktarırken kullandığı başlıklar Başbakan'ın savaş yanlısı ve sert üslubunun deşifre edilmesine dönük hamleler olarak okunabilir. Birgün Gazetesi'nde yer alan haberlerin başlıklarındaki alıntılarda Başbakan Erdoğan'ın açıklamaları ve iktidar partisinin politikalarına yönelik karşı tutum net bir biçimde yansımaktadır. Tezkerenin kabul edilmesinden hemen sonraki gün olan 5 Ekim'de yer verdiği 'Türkiye'nin büyük oyununa dikkat' başlıklı haberde ise gazetenin, uluslararası bir gazetede konunun yansımasını ele alarak Türkiye-Suriye ihtilafını Türkiye hükümetinin bir "oyunu" ve "çıkar çatışması" olarak yorumladığı söylenebilir.

Ulusal ve resmi ideolojiye yakın modernist ve milliyetçi bir editoryal çizgide yayın yapan Hürriyet Gazetesi'nde ise konuyla ilgili 20 adet haber yer almıştır:

Tablo 3: Hürriyet Gazetesi'nde 2-10 Ekim 2012 Tarihleri Arasında Çıkan Ilgili Haber Başlıkları

\begin{tabular}{|c|c|c|}
\hline Tarih & Haber Başı̆̆ı & Haberin Kaynağı \\
\hline 02.Eki & Esad'ın Halep'e gittiği iddia edildi & El Diyar- Lübnan \\
\hline 04.Eki & Tezkere TBMM'den geçti & Hürriyet \\
\hline 04.Eki & İşte tezkeredeki ince ayrıntı & Hürriyet \\
\hline 04.Eki & İnce: Esad'ın canı cehenneme & Hürriyet \\
\hline 04.Eki & 3 misliyle yanıt verildi & Hürriyet \\
\hline 04.Eki & Akçakale'de hırsızlık arttı & Doğan Haber Ajansı (DHA) \\
\hline 04.Eki & Hükümetten ilk yorum & Hürriyet \\
\hline 04.Eki & Bahçeli kararını açıkladı & Anadolu Ajansı (AA) \\
\hline 05.Eki & Gölcük Donanmada büyük hareketlilik & Doğan Haber Ajansı (DHA) \\
\hline 05.Eki & Esad mesajı aldı & Hürriyet \\
\hline 05.Eki & Erdoğan: Sekiz kere kaza mı olur & Hürriyet \\
\hline 05.Eki & Esadçısından da isyancısından da bıktık artık & Hürriyet \\
\hline 05.Eki & Dev tezkere anketinin sonucu & Hürriyet \\
\hline 06.Eki & Davutoğlu: Kim saldırırsa susturulacak & Anadolu Ajansı (AA) \\
\hline 06.Eki & Suriye'ye yine karşılık verildi & Doğan Haber Ajansı (DHA) \\
\hline 06.Eki & Genelkurmay'dan açıklama: Giriş çıkış yok & Anadolu Ajansı (AA) \\
\hline 06.Eki & Savaşın meraklısı değiliz & Hürriyet \\
\hline 07.Eki & Halep kaçkını & Hürriyet \\
\hline 08.Eki & TMO'nun bahçesine bomba düştü & Hürriyet \\
\hline 08.Eki & Top atana gül atmak ihanettir & Hürriyet \\
\hline 09.Eki & Kılıçdaroğlu: Biri kanla bastırıyor biri cezaeviyle & Hürriyet \\
\hline
\end{tabular}

Hürriyet Gazetesi kendi haberleri dışındaki haberlerde DHA ve AA gibi ülkenin önde gelen büyük ve ana akım haber ajanslarından beslenmiştir. DHA, Hürriyet'in de parçası olduğu Doğan Holding'in iştirakidir. Gazete, Türkiye'nin savaşa girmesinin önünü açacak olan tezkerenin kabulünü Tezkere TBMM'den geçti başlığıyla duyurmuştur. Gazetenin haber başlıklarına bakıldığında savaş 
karşıtı veya açıkça destekçisi olmadığı görülmektedir. Ancak haberlerde seçtiği kelimelerdeki Suriye'ye yönelik yanıt, karşılık verme, bastırma gibi ifadelerle Türk milliyetçiliğinin, militarizmin ve ulusalcılığın baskın olduğu görülmektedir. Gazete örtük olarak Türkiye'nin asker gücünü vurgulamaktadır. Gazetenin Esadçısından da isyancısından da bıktık artık ve Erdoğan: Sekiz kere kaza mı olur başlıklı haberleri ise olası bir sınır ötesi müdahaleyi destekler niteliktedir. Gazetenin başlıklarında referans verdiği isimler Bașbakan R.T. Erdoğan, CHP Genel Bașkanı Kemal Kılıçdaroğlu, CHP milletvekili Muharrem Ince, Dışişleri Bakanı Ahmet Davutoğlu ve MHP Genel Başkanı Devlet Bahçeli gibi siyasetçilerdir.

\subsection{Kimlere Söz Verildi?}

Çalışmanın bu bölümünde her iki gazeteden beş adet haber detaylı olarak incelenmiștir. Her iki gazetede de farklı kiși ve kurumlara söz verilmiștir. Așağıdaki tabloda inceleme kapsamına alınan haberlerde hangi gazetede kimlere söz verildiği görülmektedir:

Tablo 4: BirGün ve Hürriyet Gazetelerinde Kimlere Söz Verildi?

\begin{tabular}{|c|c|c|c|c|}
\hline $\begin{array}{l}\text { Gazete } \\
\text { Adı }\end{array}$ & Tarih & Haberin Başlığı & Söz Verilen Kişi ve Ünvanı & Ülke \\
\hline Hürriyet & 04.Eki & Tezkere TBMM'den geçti & TBMM & Türkiye \\
\hline Hürriyet & 04.Eki & Akçakale'de hırsızlık arttı & Vatandaş, Galip Mendi (Orgeneral) & Türkiye \\
\hline Hürriyet & 05.Eki & $\begin{array}{l}\text { Esadçısından da } \\
\text { isyancısından da bıktık artık }\end{array}$ & Vatandaş & Türkiye \\
\hline Hürriyet & 06.Eki & Savaşın meraklısı değiliz & Recep Tayyip Erdoğan (Başbakan) & Türkiye \\
\hline Hürriyet & 07.Eki & Halep kaçkını & & \\
\hline Birgün & 04.Eki & $\begin{array}{l}\text { Savaş için tezkere değil } \\
\text { şimdi barış zamanı }\end{array}$ & $\begin{array}{l}\text { Bilge Seçkin Çetinkaya (siyasetçi), } \\
\text { Alper Taş(Siyasetçi) }\end{array}$ & Türkiye \\
\hline Birgün & 04.Eki & $\begin{array}{l}\text { CHP ve BDP 'Hayır' } \\
\text { diyecek }\end{array}$ & $\begin{array}{l}\text { Nurettin Canikli (iktidar partisi } \\
\text { milletvekili), Muharrem İnce (ana } \\
\text { muhalefet partisi milletvekili) }\end{array}$ & Türkiye \\
\hline Birgün & 05. Eki & Savaşa yakın barışa Fransız & Recep Tayyip Erdoğan (Başbakan) & Türkiye \\
\hline Birgün & 10.Eki & $\begin{array}{l}\text { "Esad'a da Obama'ya da } \\
\text { 'Canın cehenneme' derim" }\end{array}$ & $\begin{array}{l}\text { Muharrem Ince (ana muhalefet } \\
\text { partisi milletvekili) }\end{array}$ & Türkiye \\
\hline Birgün & 10. Eki & $\begin{array}{l}\text { Erdoğan: Suriye'de } \\
\text { olayların bugün geldiği } \\
\text { nokta, Türkiye'nin eseri } \\
\text { değildir }\end{array}$ & Recep Tayyip Erdoğan (Başbakan) & Türkiye \\
\hline
\end{tabular}

Her iki gazetede de söz verilen tüm kişi ve kurumlar Türkiye'dedir. Hürriyet Gazetesi Tezkere TBMM'den geçtibaşlıklı haberinde TBMM'deki milletvekillerinin tartışma ve yorumlarını aktarmıştır. Tezkerenin geçtiği gün hazırlanan dosya çalışmasında ise Akçakale'deki vatandaşlarla görüşmeler yapılmış ve Galip Mendi (Orgeneral)'nin görüşü alınmıştır. Burada görüşü alınan vatandaşların "Bıktık artık Suriyelilerden, isyancısından da, Esadçısından da" ifadeleri ile tezkerenin kabul tartışmaları bir arada verilerek olası bir sınır ötesi müdahalenin desteklendiği görülmektedir. 6 Ekim tarihli haberde ise Başbakan'ın Savaşın meraklısı değiliz sözleri haber başlığına alınmıștır. Bu noktada tezkere sonras ulusal ve uluslararası çaptaki protestoların ve gelen tepkilerin etkisiyle Başbakan'ın savaş yanlısı olmadıklarını açıklama ihtiyacının gazetedeki yansıması görülmektedir.

Birgün Gazetesi ise tezkerenin kabul edildiği gün Savaş için tezkere değil şimdi barış zamanı başıılı haberinde ÖDP'nin basın açıklamasını yayınlamıştır. ÖDP, hem iktidar partisi hem de savaş karşıtı bir açıklama yayınlamıştır ve bu söylem Birgün gazetesinin sol/sosyalist ve muhalif duruşuyla uyumludur. Birgün Gazetesi, 4,5 ve 10 Ekim tarihli diğer haberlerinde ise siyasetçilere söz vermiştir. Bu noktada iktidar partisine yönelik eleştiriler ve olası bir Suriye operasyonuna karşı söylemler ağırlık kazanmaktadır.

\subsection{Haberlerin Değerlendirilmesi: Metin Semantiği, Haber Şeması, Üslup-Retorik ve Sosyo Kültürel Bağlam}

\section{Hürriyet-Tezkere TBMM'den geçti}

Türk Silahlı Kuvvetleri'nin yabancı ülkelere gönderilmesive görevlendirilmes konusunda hükümete 1 yıl süreyle yetki verilmesini öngören Başbakanlık Tezkeresi, TBMM Genel Kurulu'nda yapılan oylamada 320 kabul, 129 ret oyuyla kabul edildi. Genel Kurul'a 100 milletvekilinin gelmemesi "Hangi parti kaç fire verdi" tartışmasını gündeme getirdi. (Tezkere TBMM'den geçti, 2012, www. hurarsiv.hurriyet.com.tr)

Yukarıdaki haberde gazetenin öznel bir söylem içerisinde olmadığı görülmektedir. "Fire vermek" deyimi ile gazete tezkere tartışmalarında partiler arasında hararetli tartışmaların yaşandığını ve kimi vekillerin bu tartışmalarda ve oylamada yer almaktan kaçındığını ima etmektedir.

\section{Hürriyet-Akçakale'de hırsızlık arttı}

Şanlıurfa'nın Akçakale ilçesine dün Suriye tarafından düşen top mermisi nedeniyle 4'ü çocuk 1'i kadın 5 kişi hayatını kaybetti. Çatışmaların şiddeti ve Suriye'nin yaptığı top atışlarının Akçakale'de yerleșim alanlarını ve vatandaşları vurmasının ardından boşalan evlere de hırsızlar dadandı. Akçakale'de yaşamını yitiren 1 anne ile $3 \mathrm{kızı}$, sabah erken saatlerde toprağa verildi. (Akçakaleıde hırsızlık arttı, 2012, www.hurarsiv.hurriyet.com.tr)

Haberde ölü sayıları belirtilirken kadın ve çocukların sayıları ayrıca belirtilmiştir. Bunun yanında Suriye'deki savaşın Türkiye'deki yerleşim alanları ve vatandaşları etkilediği ve evlere hırsızların dadandığı ifade edilmektedir. Haberde halkın, resmi bir görevli olan orgenerale tepkilerini içeren "Sizi bu kadar kişı koruyor, bizi neden koruyan yok" alıntısı ile devlete yönelik tepkiler ve halkın 
isyanı daha fazla görünür kılınmıştır. Üslup ve retorik açısından bakıldığında şiddet, hırsızlık ve ölüm ifadeleri bir arada kullanılarak Suriye'de yaşanılan şiddet ortamının Türkiye sınırlarını ve halkı etkilediği vurgulanmaktadır.

\section{Hürriyet-Esadçısından da isyancısından da bıktık artık}

Mahalleli, 15-20 gündür doğru düzgün uyuyamadıklarını anlatıyor. Sınır bölgesindeki tel örgüler açılmıs ve kendi deyimleriyle sınır "yolgeçen hanına dönmüş". (Esadçısından da isyancısından da bıktık artık, 2012, www.hurarsiv. hurriyet.com.tr)

Tezkerenin kabul edildiği gün yayınlanan bu haberde Hürriyet muhabirleri Akçakale'ye giderek halkla görüşmeler yapmışlardır. Bombaların patladığı mahalledeki kesimlerle görüşen muhabirler halkın Suriyeli göçmenlerden duydukları rahatsızlıkları aktarırken bölgenin "yolgeçen hanına" döndüğü ifadesini kullanmışlardır. Yolgeçen hanı Van Dijk'ın da belirttiği gibi metin semantiğindeki deyimlerin kullanılmasına örnektir. Burada yolgeçen hanı ile kastedilen Suriyelilerin sınırda kontrol olmaksızın rahatça Türkiye'ye ve bölgeye girdiğidir. Bu rahat giriş çıkıs durumu güvenliksizlikle ilișkilendirilmiștir. "Esadçı" ve "isyancı" kelimeleri ise Suriye'de yaşanan savaştaki iki tarafı belirtmek için kullanılmıştır. Akçakale'de konuşan bir vatandaşın sözlerinden yapılan alıntı Türkiye'de yaşayanların Suriyeli göçmenlerden "bıktıkları"nı ifade etmektedir. Bıkmak ile dayanamaz duruma gelmek kastedilmektedir. Bu alıntının haber başlığında da kullanılması ile gazete Suriye'deki savaşın Türkiye'ye olan etkilerinin dayanılamaz duruma geldiğini belirtmektedir. Bu haber tezkerenin onaylanmasını meşrulaşmasını destekler niteliktedir.

\section{Hürriyet-Savaşın meraklısı değiliz}

Başbakan Tayyip Erdoğan, dün Esenler, Havaalanı Mahallesi'nde düzenlenen kentsel dönüşüm töreninde tezkerenin TBMM'den geçmesi üzerine "Bakanların hangisinin çocuğu oraya gidiyor" eleştirilerine yanıt verdi. "Asla savaş meraklısı değiliz, ancak savaştan da uzak değiliz" (Savaşın meraklısı değiliz, 2012, www.hurarsiv.hurriyet.com.tr)

6 Ekim tarihli bu haber tezkerenin kabul edilmesine yönelik tepkilerin yoğunlaştığı bir tarihte Başbakan Erdoğan'ın açıklamalarını içermektedir. Haber bașlığında referans olarak Başbakanın sözleri kullanılarak gazetenin muhabirlerinin hükümete yönelik eleştirilere verilen cevapları aktarma gayretinde olduğu görülmektedir. Bu haberin başlığındaki savaş meraklısı olmama ama kararlı olma vurgusu görselle pekiştirilmiştir.

\section{Hürriyet-Halep kaçkını}

Suriye'deki çatışmalardan kaçan 506 Suriyeli, dün Hatay'ın Reyhanlı ilçesine bağlı Bükülmez köyünden Türkiye'ye girdi. Halep ve çevresindeki yerleşim alanlarını terk ederek geldikleri Türkiye'ye sığınma talebinde bulunan Suriyeliler, sınırda yapılan işlemlerinin ardından Reyhanlı Hac Konaklama Tesisleri'ne götürüldü. Günlük kullanım eşyalarını da getiren Suriyeliler, işlemlerinin ardından Adıyaman'daki kampa gönderildi. (Halep Kaçkını, 2012 www.hurarsiv.hurriyet.com.tr)

Gazete "Halep Kaçkını" başlığıyla Suriye'den göç eden kişiler kastetmektedir. Bir yerden veya bir ișten kaçmıs kimse anlamına gelen "kaçkın" kelimesi, mülteci ya da savaş mağduru yerine kullanılmıştır. Haberin içerisinde de "Suriyeliler" ifadesi kullanılmaktadır. Suriyelilerin "günlük kullanım eşyaların da getirdiğinin" ve "sığınma taleplerinin" belirtilmesi çatışmaların etkilerin vurgulamakta ve halkın mağduriyetini öne çıkarmaktadır.

\section{Birgün-Savaş için tezkere değil şimdi barış zamanı}

Özgürlük ve Dayanışma Partisi tarafından yapılan açıklamada, Akçakale'ye top mermisi düşmesi sonucu 5 kişinin yaşamını yitirmesinin ardından Türkiye'nin Suriye'yi topçu atışıla vurduğunu ilan etmesi ve Meclis'te görüşülen savaş tezkeresine karşı "Suriye'ye yönelik sürdürülen örtülü emperyalist müdahaleye AKP'nin savaşçı politikalarına ve Tezkere ye karşı barış için sesimizi yükseltme zamanıdır." denilirken, savaş hazırlıklarını barış barikatı ile durdurma çağrıs yapıldı. (Savaş için tezkere değil șimdi barış zamanı, 2012, www.birgun.net)

ÖDP'nin açıklamasının yayınlandığı bu haberde tezkere "savaş tezkeresi" olarak belirtilmiştir. Haberde ÖDP açıklamasının Suriye'deki savaşı örtülü emperyalist müdahale olarak nitelendirdiği bölüm giriş paragrafında yer almaktadır. Bu, gazetenin sol/sosyalist duruşuyla paraleldir. Tezkerenin kabulünün savaş anlamına geldiği net olarak ifade edilmektedir. Bir yolu veya geçid kapamak için her türlü araçtan yararlanılarak yapılan engel olan "barikatların" savaşa karşı kurulması çağrısı ile Suriye'ye yönelik olası müdahalenin engellenmesi için çağı yapılmaktadır.

\section{Birgün-CHP ve BDP 'Hayır' diyecek}

Akçakale olayının ardından hükümete Suriye için sınır ötesi operasyon yetkisi veren tezkere Meclis'te kapalı oturumla görüşülüyor. Oturum öncesi CHP, tezkereye 'hayır' deme kararı alırken, BDP'nin de benzer tutum içinde olduğu kaydediliyor (CHP ve BDP 'Hayır' diyecek, 2012, www.birgun.net)

Tezkere görüşmelerinin yapıldığı dönem yayınlanan haberde CHP ve BDP gibi iki muhalefet partisinin tezkereye "Hayır" diyeceği haber başlığında belirtiliyor. Gazete böylece "Hayır" diyenleri belirterek savas karșıtı tutumunu yansıtıyor. Haberde kapalı oturum yapılmasına dönük eleştirilere karşı AKP Grup Başkanvekili Nurettin Canikli'nin “'Tarafınızı belli edin. Esad'dan yana mısın, Türkiye'den yana mısınız?" sözleri ile CHP Grup Başkanvekili Muharrem Ince, "Esad'ın canı cehenneme. Ben Türkiye Cumhuriyeti'nden yanayım" sözleri alıntılanarak CHP-AKP veya iktidar-muhalefet tartışmaları aktarımıştır. Kapal oturum yapılmasının Türkiye Cumhuriyeti'nden yana olmakla ilişkilendirildiğ tartışmaya dönük imalı bir dil kullanıımıştır.

\section{Birgün-Savaşa yakın barışa Fransız}

"Savaștan uzak değiliz" diyen Erdoğan, ülkede ve bölgede barıș isteyenlere "Yeri gelir o zamanda cenk, barışın anahtarı olur. Benim vatandaşım şehit 
edilecek, eee biz hala 'barış' diyeceğiz. Ne barışı? Ne barışı." sözleriyle karşılık verdi. Kentsel Dönüşüm'ün başlatılacağı Esenler Havaalanı Mahallesi'ndeki törende Akçakale olayı ve sonrasında Meclis'ten geçen savaş tezkeresine değindi. Erdoğan, "Biz asla savaş meraklısı değiliz. Ancak savaştan da uzak değiliz. Bu millet, yeri gelmiş kıtalar arası savaşları görerek, savaşarak bugünlere gelmiş" dedi. (Savaşa yakın barışa Fransız, 2012, www.birgun.net)

Haber, Başbakan'ın tezkerenin mecliste kabul edilmesine yönelik protesto ve eleştirilere cevaben yaptığı açıklamalarını aktarmaktadır. Hürriyet Gazetesi'nde de yer alan ve çalışma kapsamında incelenen bu haberde ise başılı "Savaşa yakın barışa Fransız" olarak konmuștur. Hürriyet Gazetesine kıyasla buradaki haber şemasında Başbakan'ın söyledikleri daha uzun bir biçimde girişte yer almış ve başıı̆a bir alıntı yerine gazetenin yorumu konmuştur. Fransız olmak, Türkiye'de kullanılan bir deyimdir ve konuya yabancı kalmak anlamında kullanılmaktadır. Buradaki kullanımda ise hükümetin savaşa yakın barışa uzak olduğuna dair bir ima söz konusudur. Haberde tezkerenin kabulünü protesto edenler barış isteyenler olarak ifade edilmekte ve Erdoğan'ın savaş yanlısı bir tutumda olduğu gösterilmektedir. Buradaki üslup ve retorik gazetenin hükümet karşıtı ve süreçte savaş karşıtı tutumuyla örtüşmektedir.

\section{Birgün- "Esad'a da Obama'ya da 'Canın cehenneme' derim"}

CHP Grup Başkanvekili Muharrem Ince, Türkiye'nin çıkarlarına zarar veren herkese "Canın cehenneme" diyebileceğini belirterek, "Esad'a da Obama'ya da 'Canın cehenneme' derim" dedi. (Esad'a da Obama'ya da 'Canın cehenneme' derim, 2012, www.birgun.net)

Muharrem Ince, ana muhalefet partisi milletvekilidir. Canın cehenneme sözü genellikle Amerikan Hollywood filmlerinde kullanılan bir deyimin Türkçe çevirisidir. Ince, bu sözüyle Esad ve emperyal güçlere dönük imalı bir yanıt oluşturmaktadır. Bu alıntıyı haber başığına taşıyan gazete de Türkiye çıkarlarına zarar verenlerin "canı cehenneme" ifadesini vurgulamaktadır. Cehennem, dinî inanışlara göre, dünyada günah işleyenlerin öldükten sonra ceza görecekleri yerdir. Dolayısıyla böyle bir ifadenin haber başlığı ve haberin girişinde vurgulanması sert bir ifadedir ve Obama veya Esad'a karşı bir Türkiye vurgusunu güçlendirerek ulusal sol vurguyu yansıtmaktadır.

\section{Birgün-Erdoğan: Suriye'de olayların bugün geldiği nokta, Türkiye'nin} eseri değildir

Başbakan Recep Tayyip Erdoğan, Suriye üzerinden asla bir çıkar hedeflerinin olmadığını iddia etti. (Erdoğan: Suriye'de olayların bugün geldiği nokta, Türkiye'nin eseri değildi, 2012, www.birgun.net)

Haberde, Başbakan Erdoğan'ın açıklamaları "iddia" olarak ifade edilerek inandırıcılığı sorgulanmaktadır. Haberde Erdoğan'ın açıklamaları aktarıımış ancak bir yorum ya da görüş belirtilmemiştir. Yapılan alıntılarda Erdoğan'ın Esad ailesinin Suriye'yi bu hale getirdiğini belirttiği aktarılmıştır.

\section{Sonuç}

Medya söylemi kişilerin bilgi, tutum ve ideolojilerinin ana kaynaklarıdır. Elbette medya bunu siyasetçiler, profesyoneller ve akademisyenler gibi diğer elitlerle işbirliği içerisinde yapmaktadır (Van Dijk 2000: 42). Gazetelerin siyasi partiler, sermaye sahipleri ve/veya ordu ile olan ilişkileri söylemlerini ve editoryal denetimlerini belirlemektedir. Türk medyasını tek bir medya olarak ele almak mümkün değildir. Farklı siyasi, ideolojik ve maddi kuvvetler Türkiye'deki basının haber yapma biçimlerini etkilemektedir.

Eleştirel Söylem Analizi ile incelenen Hürriyet ve Birgün gazetelerinin haberlerindeki söylemlerinde gazetelerin editoryal duruşlarının etkileri görülmektedir. Hürriyet Gazetesi, kimi zaman açık kimi zaman da örtük bir biçimde Türk milliyetçiliğini ve ulusalcılığı öne çıkarmaktadır. Birgün Gazetesi'ndeki haberlerde ise sol/sosyalist duruşunun ve hükümet karşıtlığının yansıdığı görülmektedir. Bu durum gazetelerin tarihçeleri ve duruşlarıyla paralellik arz etmektedir.

Suriye'deki iç savaşın Türkiye'yi fiziksel anlamda da etkilemeye başladığı ilk tarih olan 3 Ekim itibariyle her iki gazetenin de özellikle Türkiye-Suriye ilişkilerine odaklandıkları ve olası bir sınır ötesi operasyona dönük haberler yaptıkları görülmektedir. Her iki gazetenin tirajları ve internet sitesi ziyaretçi sayılarına bakıldığında Hürriyet Gazetesi'nin, Birgün Gazetesi'ne kıyasla çok daha fazla kișiye ulaștığı ve etkileme gücünün daha yüksek olduğu görülmektedir. 2003 yılında Irak'ta yaşanan savaşa dair Türkiye'de gerçekleştirilen tartışmalarda Türk medyasının savaş yanlıı̆̆ı sıklıkla sorgulanmıştır. 2012'de Suriye'de yaşanan savaşın medya açısından daha temkinli ele alındığı görülmektedir. Türkiye'deki kamuoyu yoklamalarında da tezkerenin kabul edilmesine karşı olanların oranının yüksek olduğu görülmektedir.

Birgün Gazetesi söyleminde açıkça savaş karşıtlı̆ı̆ıı gösterirken bunu emperyal düzene ortak olmamak, Suriye'deki oyuna katılmamak ve hükümet karşıtlığı ile haklılaştırmaktadır. Hürriyet gazetesi ise söyleminde açıkça savaş karşıtlığı yapmasa dahi "ulusal çıkarların" önde olduğu haber söylemi benimsemiştir.

\section{Kaynakça}

Kitap

BESEN Haluk (1997), Türkiye'de Gazetecilik, Gazeteler, Gazeteciler, İnkılap Yayınları.

ÇOMAK Nebahat ve INCEOĞLU Yasemin (2000), Metin Çözümlemeleri, İstanbul: Ayrıntı Yayınları. 
GÜNEY Zeynep ve SÖZERi Ceren (2011), Türkiye'de Medyanın Ekonomi Politiği: Sektör Analizi. TESEV Yayınları.

iNUĞUR M. Nuri (1993), Basın ve Yayın Tarihi, Der Yayınları, 3. Basım.

ORAN Baskın (2001), Türk Dış Politikası Cilt I - II, İstanbul: İletişim Yayınları.

VAN DIJK Teun A (1988), News Analysis: Case Studies of International and National News in the Press, Hillsdale, New Jersey.

VAN DIJK Teun A (2000), Ideology and Discourse: A Multidisciplinary Introduction, Universitat Oberta de Catalunya.

VAN DIJK Teun A (1984), Structures of International News: A Case Study of The World Press, UN, Paris.

VAN DIJK Teun A (1988), News As Discourse. New Jersey: Hillsdale.

\section{Makale}

CANGÖZ İncilay (2003), "Savaş İhtimalinin Türkiye'de Yazılı Basında Temsili", Savaş ve Medya, Anadolu Üniversitesi Yayınları.

ÇAKIR Ahmet (2001), "Basın tarihi: Sansür tarihi”, Radikal.

VAN DIJK Teun A (1995), "Ideological Discourse Analysis", Special Issue Interdisciplinary Approaches to Discourse Analysis, New Courant (English Dept, University of Helsinki).

VAN DIJK Teun A (2000), "New(s) Racism: A discourse analytical approach." Simon Cottle (Ed.), Ethnic Minorities and the Media. Milton Keynes, UK: Open University Press.

\section{internette Makale}

ALTINDIŞ Emrah (2009), "ÖDP ve Birgün gazetesi", http://www.turnusol. biz/public/makale. aspx? id=4441\&pid=16\&makale=\% D6DP\%20ve\% 20 Birg\%FCn\%20gazetesi, 15.05.2013.

DUNHAM Jennifer ve KARLEKAR Karin Deutsch (2013). "Press Freedom in 2012: Middle East Volatility Amid Global Decline", http://www.freedomhouse. org/sites/default/files/Booklet\%20Essay.pdf.

VAN DIJK Teun A (2013), "The Interdisciplinary Study Of News As Discourse", http://www.discourses.org/OldArticles/The\%20interdisciplinary\%20study\% 20 of\%20news \%20as\%20discourse.pdf, 16.05.2013.

Mayıs 2013 Tiraj Raporu, Basın Illan Kurumu, http://www.bik.gov.tr/istanbul/ mayis-2013-tiraj-raporu, 2013
TUiK (2011), “Yazılı Medya İstatistikleri”, http://www.tuik.gov.trNeriBilgi.do?alt_ $\mathrm{id}=15,13.05 .2013$.

DOĞAN YAYIN HOLDING, "Yazılı Basın Yayın Illkeleri" http://imagehk.hurriyet. com.tr/UserFiles/DYGYBYI.pdf, 14.05.2013

"Neden Bir Günlük Gazete? Nasıl Bir Günlük Gazete?", Birgün, http:// www.birgun.net/content_index.php?category_code $=1094802789 \&$ news_ code $=1184802801$.

"Tezkere TBMM'den geçti", Hürriyet Gazetesi, http://hurarsiv.hurriyet.com.tr/ goster/haber. aspx?id=21622897\&tarih=2012-10-04, 4 Ekim 2012, (21.05.2013)

KIRMIZITAŞ Hasan, KURT Hadi ve ŞULUL Ömer (2012), “Akçakaleıde hırsızlık arttı", Hürriyet Gazetesi, http://hurarsiv.hurriyet.com.tr/goster/haber.aspx?id=2 1620417\&tarih=2012-10-04, 21.05.2013.

KÖKER İrem (2012), “Esadçısından da isyancısından da bıktık artık”, Hürriyet Gazetesi, http://hurarsiv.hurriyet.com.tr/goster/haber.aspx?id=21627607\&tar ih=2012-10-05, 21.05.2013.

SEREST Eyüp (2012), "Savaşın meraklısı değiliz", Hürriyet Gazetesi, http:// hurarsiv. hurriyet.com.tr/goster/haber. aspx? id=21635236\&tarih=2012-10-06, 21.05.2013.

"Halep kaçkını", Hürriyet Gazetesi, http://hurarsiv.hurriyet.com.tr/goster/haber aspx?id=21640645\&tarih=2012-10-07, 07 Ekim 2012, (21.05.2013).

"Savaş için tezkere değil şimdi barış zamanı", Birgün,http://www.birgun.net/ politics_index.php?news_code $=1349339533$ \&year $=2012 \&$ month $=10 \&$ day $=04$, 4 Ekim 2012, (22.05.2013)

"CHP ve BDP 'Hayır' diyecek", Birgün, http://www.birgun.net/politics_index. php?news_code $=1349339912 \&$ year $=2012 \&$ month $=10 \&$ day $=04$ ， 4 Ekim 2012 (22.05.2013)

"Savaşa yakın barışa Fransız", Birgün, http://www.birgun.net/politics_index php?news_code $=1349425514$ \&year $=2012 \&$ month $=10 \&$ day $=05,5$ Ekim 2012, (22.05.2013).

"Esad'a da Obama'ya da 'Canın cehenneme' derim", Birgün, http://www. birgun.net/politics_index.php?news_code $=1349858492 \&$ year $=2012 \&$ month $=1$ 0\&day=10, 10 Ekim 2012, (22.05.2013)

“Erdoğan: Suriye'de olayların bugün geldiği nokta, Türkiye'nin eseri değildir", Birgün, http://www.birgun.net/politics_index.php?news_code $=1349858191 \& y$ ear $=2012 \&$ month $=10 \&$ day $=10,10$ Ekim 2012 